\title{
An InTRODUCTION TO THE FedERAL SENTENCING GUIDELINES
}

\author{
JEFF PAPA* \\ CHRIS KASHMAN**
}

\section{INTRODUCTION}

The Federal Sentencing Guidelines were originally imposed by Congress in the Sentencing Reform Act of 1984 (SRA). ${ }^{1}$ This statute was an attempt to create a determinate sentencing system, which included large-scale elimination of parole and severe restriction of good time credit in order to create a system in which criminals would serve most or all of the time to which they were sentenced. ${ }^{2}$

For nearly 100 years prior to the enactment of the SRA, the U.S. federal criminal system was an indeterminate sentencing system, under which "[s]tatutes specified the penalties for crimes but nearly always gave the sentencing judge wide discretion"3 in whether an individual should be incarcerated and for how long, and as to whether the use of parole was appropriate. ${ }^{4}$

In order to establish the actual definitions and sentencing structure to be used under the SRA, Congress created the U.S. Sentencing Commission. ${ }^{5}$ The purposes of this Commission were to assure the purpose of the new sentencing system was met;

to avoid[ ] unwarranted sentencing disparities among defendants with similar records who have been found guilty of similar criminal conduct while maintaining sufficient flexibility to permit individualized sentences when warranted by mitigating or aggravating factors not taken into account in the establishment of general sentencing practices ${ }^{6}$;

and to reflect the current state of advancement of human knowledge regarding the criminal justice system. ${ }^{7}$

As originally enacted, the SRA required district courts to impose mandatory sentences of the kind, and within the range, set out in the Guidelines. The only major exception to this was if the court felt that there was "an aggravating or

* Partner, Barnes \& Thornburg LLP, B.S., Rose-Hulman Institute of Technology; M.A., Ball State University; J.D., Indiana University School of Law-Indianapolis; L.L.M., Indiana University School of Law - Indianapolis; PhD, Indiana State University.

** Associate, Ice Miller LLP, B.S., Finance, Indiana University, Kelley School of Business; J.D., Loyola University of Chicago School of Law.

1. Sentencing Reform Act of 1984, Pub. L. 98-473, 98 Stat. 1987 (1984); see 18 U.S.C. $\S$ 3553 (2012).

2. U.S. Sentencing Guidelines Manual ch. 1, pt. A (U.S. Sentencing Comm'n 2016).

3. Mistretta v. United States, 488 U.S. 361, 363 (1989).

4. $I d$.

5. 28 U.S.C. $\$ 991(a)(2012)$.

6. Id. $\S 991(\mathrm{~b})(1)(\mathrm{B})$.

7. Id. $\S 991(\mathrm{~b})(1)(\mathrm{C})$. 
mitigating circumstance of a kind, or to a degree, not adequately taken into consideration by the Sentencing Commission in formulating the [G]uidelines" that justified a variation in the sentence. ${ }^{8}$ Some variation was also allowed in the case of child crimes and sexual offenses. ${ }^{9}$

The SRA directed courts to impose sentences that are "sufficient, but not greater than necessary, to comply with the purposes set forth [in the statute]." The considerations to examine in order to achieve these purposes included: the nature and circumstances surrounding the offense and history of the defendant, the need for the sentence to reflect the seriousness of the offense, the need to promote respect for the law and provide fair punishment, the need to consider the goal of deterring criminal conduct and protecting the public from further crimes, and the goal of providing the defendant with needed education and treatment. ${ }^{11}$ The sentence was also to take into consideration the types of sentences available, the interplay between the type of offense committed and the defendant's criminal history, any pertinent policy statements, the need to avoid unnecessary sentencing disparities, and the need to provide restitution to victims of the offense. ${ }^{12}$

This sentencing system called for the imposition of sentences, using a grid system, which took into account the type of crime as well as the convicted defendant's prior history. ${ }^{13}$ This grid is composed of two axes of numerical level values; one representing the criminal history category into which the offender has been placed and one representing the level assigned to the present offense of which the offender has been convicted. ${ }^{14}$

The vertical axis of the sentencing grid or table contains forty-three Offense Levels, depending on the severity and type of the crime committed. ${ }^{15}$ The horizontal axis of the sentencing table contains six levels of Criminal History Category. ${ }^{16}$ Criminal History Category is assigned based on the offender's past criminal record, according to total criminal history points afforded to that individual under Chapter Four, Part A of the Sentencing Guidelines. ${ }^{17}$ The current Sentencing Table is attached to this paper as Appendix A. ${ }^{18}$

A sentencing range is determined under the Guidelines by finding the proper Offense Level and then moving across the corresponding row of the Sentencing Table to the column representing the correct Criminal History Category for the offender. Sentence ranges are expressed in terms of months of imprisonment,

\footnotetext{
8. 18 U.S.C. $\S 3553(b)(1)$ (2012).

9. Id. $\S 3553(\mathrm{~b})(2)$.

10. Id. $\S 3553(\mathrm{a})$.

11. Id.

12. $I d$.

13. Id. $\S 3553(\mathrm{~b})$.

14. U.S. Sentencing Guidelines Manual ch. 5, pt. A (U.S. Sentencing Comm'n 2016).

15. Id.

16. Id.

17. Id. cmt. n.3.

18. See infra Appendix A.
} 
from zero to life imprisonment. ${ }^{19}$

This means that the sentence for a given crime, committed at a certain level of seriousness, is assigned on a sliding scale taking into consideration the offender's past criminal history. For example, a crime committed at an Offense Level of 8 (after adjustment) carries a sentencing range of 0-6 months for an offender with a Criminal History category of I, but is assigned a sentence of 6-12 months where a Criminal History Category of III is found, and a sentence range of 18-24 months where a Criminal History Category of VI is found..$^{20}$ The original statute also set forth various standards of appellate review for the actions of the federal district courts that would apply the grid. ${ }^{21}$ Each range in the Sentencing Table overlaps with the ranges that come before and after it; this discourages unnecessary litigation over a small difference of appropriate level in that the same penalty (or nearly so) may be imposed even if a level were to be reassigned. ${ }^{22}$

Use of the Sentencing Table also must take into account the statutory penalties for any given crime. Where the statutory maximum penalty is less than the minimum of the Guideline range, the statutory maximum is considered the Guideline sentence. ${ }^{23}$ Where the statutory minimum penalty is greater than the maximum of the Guideline range, the statutory minimum is considered the Guideline sentence. ${ }^{24}$ Otherwise, the sentence may be one within the Guidelines range provided such sentence is not greater than the statutorily allowed maximum sentence or less than the statutorily allowed minimum sentence. ${ }^{25}$

Criminal History Category for a given offender is assigned by adding the total points from seven separate considerations. Three points are assigned for each prior sentence of imprisonment exceeding thirteen months; two points are added for each prior sentence of at least sixty days not already counted; one point is added (maximum four) for each prior sentence not yet counted; two points are added if the offense was committed while still under the jurisdiction of a prior sentence such as probation or parole; one or two points may be added if the offense was committed sooner than two years from release from imprisonment; and up to three more points may be added for additional prior convictions that did not result in additional sentencing time. ${ }^{26}$

These total points are then applied to determine the Criminal History Category. Zero to one point results in Criminal History Category I; two or three points results in Criminal History Category II; four, five or six points results in Criminal History Category III; and so on until reaching thirteen or more points,

19. U.S. Sentencing Guidelines Manual ch. 5, pt. A, cmt. n.1.

20. Id. ch.5 pt. A (using chart to illustrate the author's example).

21. 18 U.S.C. $\S 3742$ (e) (2012).

22. U.S. Sentencing Guidelines Manual ch. 5, pt. A.

23. Id. §5G1.1(a).

24. Id. §5G1.1(b).

25. Id. $\S 5 \mathrm{G} 1.1(\mathrm{c})(1)-(2)$.

26. Id. $\S 4 \mathrm{~A} 1.1(\mathrm{a})-(\mathrm{e})$. 
which yields Criminal History Category VI. ${ }^{27}$

Offense Levels are generally determined by referring to the Base Offense Level for the given crime, as listed in Chapter 2 of the Guidelines, and then applying any adjustments specific to the given conviction. ${ }^{28}$ For example, the Base Offense Level for obscene telephonic communication for a commercial purpose or broadcasting obscene material is $12 .{ }^{29}$ However, as one example of an adjustment, this may be enhanced by four levels, if the recipient was under "eighteen years of age, or if a broadcast was made between six [a.m.] and eleven [p.m]." ${ }^{30}$

Adjustments to the Offense Level may also be made where positive and/or negative factors exist, where those factors have been considered by the Commission and set out in the Guidelines. Chapter Three of the Guidelines Manual enumerates some of these various enhancements (for example, a hate crime can enhance the Offense Level by three to five levels) ${ }^{31}$ and reductions (for example, if the offender was a minimal or minor participant in the crime the Offense Level may be reduced by two to four levels). ${ }^{32}$ Further adjustments may be made based on other factors, such as the offender's acceptance of responsibility, multiple convictions, victim considerations, obstruction of justice, and other factors. ${ }^{33}$

Under the SRA, a judge normally selects a sentence from the appropriate range suggested by the Guidelines. If the case involves unusual circumstances, then the judge may depart from the guideline range, but must explain the departure. ${ }^{34}$ The SRA, as enacted, permitted a judge to depart from the Guidelines only where a mitigating or aggravating factor was found, which had not been properly considered by the Commission. ${ }^{35}$

Within the Guidelines, the normal range of sentences was intended to be closely-defined. The maximum penalty set for any range may not exceed the minimum penalty by more than the greater of six months or twenty-five percent. ${ }^{36}$ The Sentencing Commission also intended that the Guidelines not begin as a major departure from existing sentencing in the fact that it attempted to estimate the average sentences within each range that were being imposed prior to imposition of the Guidelines. ${ }^{37}$

27. Id. ch.5, pt. A.

28. Id. $\S 1 \mathrm{~B} 1.1$.

29. Id. $\S 2 \mathrm{G} 3.2(\mathrm{a})$.

30. Id. $\S 2 \mathrm{G} 3.2(\mathrm{~b})(1)$.

31. Id. $\S 3 \mathrm{~A} 1.1$ (addressing hate crime motivation or vulnerable victims).

32. Id. § 3B1.2 (mitigating role).

33. Id. $\S 1 \mathrm{~B} 1.1$.

34. 18 U.S.C. $\S 3553(b)-(c)(2012)$.

35. Id.

36. 28 U.S.C. $\S 994(b)(2)(2012)$.

37. 2016 U.S. Sentencing Guidelines Manual ch. 1, pt. A.1.3. The Commission attempted to resolve the tension between a just desserts and a practical crime control philosophy by analyzing empirical data from 10,000 presentence investigation reports to determine how sentencing was 


\section{SIGNIFICANT CASES IMPACTING THE SRA}

In Mistretta v. United States,${ }^{38}$ Mistretta challenged his sentence for cocainerelated crimes. ${ }^{39}$ He argued that the SRA and its Guidelines were unconstitutional on the grounds that the Act violated the Separation of Powers Doctrine by placing the Commission in the Judicial Branch and that Congress had delegated excessive authority to the Commission to create the Guidelines. ${ }^{40}$

The Court held that Congress had not delegated excessive authority to another branch of government, and had not upset the constitutionally-mandated balance of power between the branches of government when it placed the Commission in the Judicial Branch. ${ }^{41}$ The Court further held that the mandated participation of judges on the Commission did not threaten the impartiality of the Judicial Branch. $^{42}$

In Koon v. United States, Koon was a police officer who appealed his sentence related to the Rodney King beating. ${ }^{43}$ The district court had granted several downward departures, and the appellate court had stricken each of these departures utilizing a de novo standard of review. ${ }^{44}$ The U.S. Supreme Court held that the proper standard of review on appeal under the SRA was abuse of discretion. ${ }^{45}$ The Court further stated that the "district court must impose a sentence within the [Guidelines], if it finds the case to be a typical one."

The Court reiterated that the SRA did not change the "traditional deference" due a trial court and its unique perspective. ${ }^{47}$ The Court also noted that a de novo standard of review would not be likely to establish clear Guidelines for the district courts to follow. ${ }^{48}$

One example of a consideration for departure found inappropriate was the

approached prior to the imposition of the guidelines. It used this data as a starting point for discussions regarding appropriate sentencing under the new guidelines.

38. 488 U.S. 361 (1989).

39. Id.

40. Id. at 370; see also United States v. Mason, 902 F.2d 1314 (8th Cir. 1990) (holding that the SRA does not violate separation of powers by delegating authority to prosecutors to control when a judge may consider the defendant's cooperation as a mitigating factor); United States v. Jones, 933 F.2d 1541 (11th Cir. 1991) (holding that SRA does not violate separation of powers by delegating legislative power to the executive branch and by usurping the judicial function).

41. Mistretta, 488 U.S. at 395.

42. Id. at 407-08.

43. 518 U.S. 81 (1996).

44. Id. at 90 .

45. Id. at 100 .

46. $I d$. at 85 .

47. Id. at 97-98.

48. Id. at 99. 
claim that Koon had a low likelihood of recidivism. ${ }^{49}$ The Court held that this factor had been taken into account by the Guidelines. ${ }^{50}$ Koon was a first-time offender and had been properly placed in criminal history category I, which takes into account the fact that this class of offender is not yet a hardened criminal with a high certainty of repeat offenses. ${ }^{51}$

In Apprendi v. New Jersey, ${ }^{52}$ Apprendi had fired a gun into an AfricanAmerican home and stated that he had done so in order to encourage them to leave the neighborhood, but later retracted that statement. ${ }^{53} \mathrm{He}$ was not charged with any hate crimes, and entered a plea agreement, under which the maximum sentence would have been ten years. ${ }^{54}$ However, under New Jersey law, a sentence could be enhanced if there was a biased purpose for commission of the crime, which could enhance the maximum penalty to a total of up to thirty years. ${ }^{55}$ The sentencing judge found a purpose of bias by a preponderance of the evidence, and sentenced Apprendi to twelve years (two more than the maximum for the crime in question). ${ }^{56}$

Apprendi appealed the sentence, arguing that such finding of bias would need to be proven beyond a reasonable doubt to a jury, rather than found by a judge by a preponderance of the evidence. ${ }^{57}$ The U.S. Supreme Court agreed with Apprendi, stating that the practice challenged by Apprendi was an "unacceptable departure from the jury tradition that is an indispensable part of our criminal justice system." 58

New Jersey had attempted to argue that the bias factor was merely a sentencing factor to be taken into consideration, not an underlying element of the crimes that required proof beyond a reasonable doubt to a jury. ${ }^{59}$ In resolving Apprendi, the Supreme Court set forth the following rule: that other than "the fact of a prior conviction, any fact that increases the penalty for a crime beyond the prescribed statutory maximum must be submitted to a jury, and proved beyond a reasonable doubt. ${ }^{, 60}$

Justice O'Connor dissented, joined by three other justices. ${ }^{61}$ She stated that

49. Id. at 111 .

50. Id.

51. Id. at 110-11; see also United States v. Gallegos, 129 F.3d 1140 (10th Cir. 1997) (holding that it was impermissible for the district court to use the defendant's lack of criminal history as the basis for a downward departure, as that was already factored into placement in Criminal History Category I).

52. 530 U.S. $466(2000)$.

53. Id. at 469 .

54. Id. at 469-70.

55. Id. at 470.

56. Id. at 470-71.

57. Id. at 471 .

58. Id. at 497.

59. Id. at 471-72.

60. Id. at 490 .

61. Id. at 523 (O'Connor, J., dissenting, with whom the Chief Justice, Justice Kennedy, and 
the Court had long recognized that not every fact bearing on a defendant's punishment need be charged, submitted to a jury, and proven beyond a reasonable doubt. ${ }^{62}$ She noted that the Court had refrained from establishing a bright-line rule for deciding that certain facts must be treated as an element of the offense despite a legislature's choice not to do so. ${ }^{63}$

Justice O'Connor claimed that the Majority opinion was unsupported by existing case law and had little basis in the Constitution. ${ }^{64}$ She also warned that the decision in Apprendi would lead to an unsettling effect in sentencing that would "unleash a flood of petitions by convicted defendants seeking to invalidate their sentences in whole or in part" based on this decision. ${ }^{65}$

Justice O'Connor was correct in that prior U.S. Supreme Court jurisprudence had allowed sentencing similar to that which Apprendi had received under New Jersey law. For example, in Williams $v$. New York, ${ }^{66}$ Williams had been convicted of murder and the jury had recommended a life sentence. ${ }^{67}$ The judge secretly reviewed a presentence report, which showed thirty prior robberies and a probation department finding that Williams had morbid sexuality, and the judge sentenced Williams to death. ${ }^{68}$ The Court upheld this sentence, stating that it was not a violation of Due Process and it was an example of the age-old process of judges seeking out of court evidence to mete out just and individualized sentences. ${ }^{69}$

Williams was overruled to some extent by Gardner v. Florida.$^{70}$ A jury had determined that mitigating circumstances outweighed aggravating factors and recommended Gardner receive a life sentence. ${ }^{71}$ The judge reviewed a secret presentence report and sentenced Gardner to death. ${ }^{72}$ The Florida Supreme Court upheld the sentence without review of the presentence report. ${ }^{73}$ The U.S. Supreme Court vacated the sentence and remanded the case, stating that "that petitioner was denied due process of law when the death sentence was imposed, at least in part, on the basis of information which he had no opportunity to deny or explain." 74

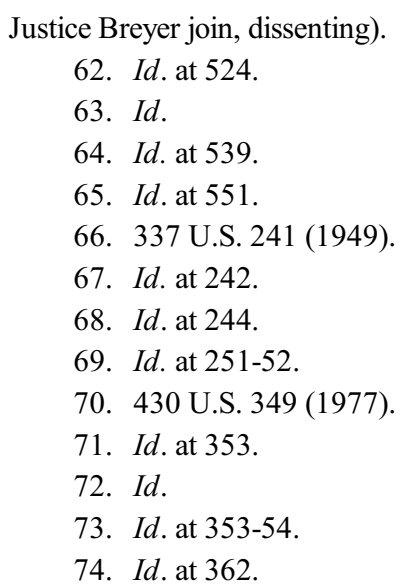


In Blakely v. Washington, ${ }^{75}$ Blakely was charged with kidnapping I and pled guilty to kidnapping II. $^{76}$ The maximum sentence for kidnapping II was fifty-three months, and the State recommended a sentence of forty-nine to fifty-three months. ${ }^{77}$ The judge, however, sentenced Blakely to ninety months. ${ }^{78}$ This sentence was thirty-seven months greater than the maximum penalty for kidnapping II. $^{79}$ The judge based the extended sentence upon a finding that, by a preponderance of the evidence, Blakely had acted with "deliberate cruelty." 80

The U.S. Supreme Court applied the Apprendi rule to the facts of the Blakely case: that other than in the case of an admission of guilt

$[U]$ nder the Due Process Clause of the Fifth Amendment and the notice and jury trial guarantees of the Sixth Amendment, any fact (other than prior conviction) that increases the maximum penalty for a crime must be charged in an indictment, submitted to a jury, and proven beyond a reasonable doubt. The Fourteenth Amendment commands the same answer in this case involving a state statute. ${ }^{81}$

Because Blakely was sentenced to more than three years beyond the maximum for deliberate cruelty, and the facts underlying that enhancement had not been admitted or found by a jury, this sentence was unconstitutional under the Apprendi rule. ${ }^{82}$

In adhering to the Apprendi rule, the Court stated that failing to do so would leave only two alternatives. ${ }^{83}$ The first would be to ensure that a jury determined only those facts the Legislature chooses to label as elements of a crime, while allowing any level of enhancement by judge for those items labeled "sentencing factors." ${ }^{84}$ The Court noted that this would lead to "absurd" results with a prosecutor only needing to gain a conviction on minor elements for the judge to then dole out massive sentences based on "factors." 85

The second alternative would be for legislatures to establish legally essential sentencing factors with limits. ${ }^{86}$ Under this idea, the judge could enhance sentences as long as the enhancement did not "go too far." ${ }^{87}$ The Court discarded this proposition as far too subjective. ${ }^{88}$ Having ruled out both of these

75. 542 U.S. 296 (2004).

76. Id. at 298 .

77. Id. at 300 .

78. Id.

79. Id.

80. Id. at 300-01.

81. 530 U.S. 466,476 (2000).

82. 542 U.S. at 313-14.

83. Id. at 306.

84. Id.

85. Id.

86. Id. at 307.

87. Id.

88. Id. 
possibilities, the Court reiterated the wisdom of continuing to follow Apprendi. ${ }^{89}$

In United States $v$. Booker,${ }^{90}$ two defendants had been convicted of charges related to cocaine distribution. ${ }^{91}$ One defendant had his sentence enhanced by more than eight years when the judge found that the defendant had possessed a greater quantity of cocaine than found by the jury; that defendant appealed..$^{92}$ The judge also made findings that would have added ten years to the second defendant's sentence but the judge did not enhance that sentence. ${ }^{93}$

The U.S. Supreme Court found that the imposition of a sentence under the Guidelines that was enhanced by the sentencing judge's determination of a fact, other than a prior conviction, that was not found by a jury or admitted by the defendant violated the Sixth Amendment of the U.S. Constitution. ${ }^{94}$ The Court held that its decision in Blakely therefore applied to the sentencing guidelines. ${ }^{95}$ The Court also held that, because the Sixth Amendment had been violated by imposition of these provisions, the portions of the federal statutes that made the Guidelines mandatory were unconstitutional and severed from the SRA. ${ }^{96}$ In doing so, the Court rendered the Guidelines advisory, and furthermore severed the standards of review imposed by Congress - including de novo review. ${ }^{97}$ The Court stated that while this left the statute with no explicit standard of review, going forward courts would review the imposition of sentences for

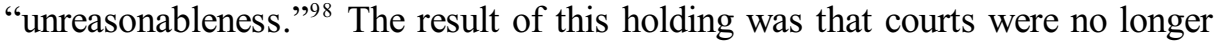
required to follow the Guidelines, but should consult them in order to determine the reasonableness of a sentence. ${ }^{99}$ Even though the Court found portions of the SRA unconstitutional, it encouraged advisory consultation with the Guidelines because this would help "avoid excessive sentencing disparities while maintaining flexibility sufficient to individualize sentences where necessary." 100

In Gall v. United States, ${ }^{101}$ the U.S. Supreme Court reaffirmed this view of the Guidelines as the proper point of reference for sentencing when it stated that

89. Id. at 307-08.

90. 543 U.S. 220 (2005).

91. Id. at 227-28.

92. Id. at 227-29.

93. Id.

94. Id. at 244 .

95. Id. at 243-44.

96. Id. at 244-46 (Justice Stevens and Justice Breyer opinions).

97. Id. at 259.

98. Id. at 261.

99. Id; see also United States v. George, 403 F.3d 470 (7th Cir. 2005) (holding that pursuant to Booker, the Guidelines continue to inform district judges' decisions).

100. Booker, 543 U.S. at 264. However, see United States v. Morrisette, 429 F.3d 318 (1st Cir. 2005) (holding that there was no Booker or Sixth Amendment violation for engaging in judicial factfinding and refusing to apply the safety valve provision for a downward departure because Booker only applies to upward enhancements of sentences, not reductions).

101. 55 U.S. 38 (2007). 
as a "matter of administration and to secure nationwide consistency, the Guidelines should be the starting point and the initial benchmark." ${ }^{102}$ The Court also reiterated the deference due the trial courts as they impose sentences after reviewing the Guidelines. ${ }^{103}$ The trial court had sentenced Gall to three years of probation, even though the Guidelines called for a minimum sentence of thirty months in prison. ${ }^{104}$

The Eighth Circuit Court of Appeals reversed, holding that a sentence outside the Guidelines must be supported by "extraordinary" circumstances, which it did not find in this case. ${ }^{105}$ The U.S. Supreme Court reversed the Court of Appeals, stating that while a trial court judge must seriously consider the Guidelines and explain any departure in sufficient detail, appellate review of sentencing under Booker is to be limited to determining whether the sentence was reasonable. ${ }^{106}$ Reasonableness is to be determined using an abuse of discretion standard and appellate courts may not require a finding of extraordinary circumstances. ${ }^{107}$ The U.S. Supreme Court determined that the Court of Appeals should have reviewed the case under an abuse of discretion standard and should have given due deference to the District Court's "reasoned and reasonable decision" in this case. $^{108}$

Although in Booker the Supreme Court rendered the Guidelines advisory in nature, Congress has the power to provide the Commission with very specific direction. In Kimbrough v. United States, ${ }^{109}$ the Court stated that "Congress has shown that it knows how to direct sentencing practices in express terms." 110

In Rita v. United States, ${ }^{111}$ Rita was convicted of crimes relating to the provision of false testimony to a grand jury. ${ }^{112}$ At sentencing, Rita argued for downward departure in his sentence due to his physical condition, vulnerability in prison, and his military record. ${ }^{113}$ The sentencing judge found no reason for departure from the recommended guideline sentence and imposed a sentence of thirty-three months with brief reasoning. ${ }^{114}$

102. Id. at 49 .

103. Id. at 51 .

104. Id. at 43 .

105. Id. at 45 .

106. Id.

107. Id. at $45-47$.

108. Id. at 59-60; see also United States v. Blackburn, No. 05-3478, 2006 U.S. App. LEXIS 6102, at*1 (7th Cir. Mar. 10, 2006) (holding that thirty month sentence imposed upon revocation of supervised release was affirmed because the court did not impermissibly depart from the Guidelines range of 8-14 months).

109. 552 U.S. 85 (2007).

110. Id. at 103; see also United States v. Bolding, 876 F.2d 21 (4th Cir. 1989) (holding that Congress may guide district court discretion through the Guidelines).

111. 551 U.S. 338 (2007).

112. Id. at 341

113. Id. at 345 .

114. Id. at 345-46. 
Rita appealed, claiming that the sentence imposed by the sentencing judge was unreasonable and had been given an unfair presumption of reasonableness at the appellate level. ${ }^{115}$ The Court concluded that when an appeals court reviews a sentence imposed by a trial judge, it may afford a presumption of reasonableness where the sentencing Guidelines have been properly applied. ${ }^{116}$ The Court also found that, while his statement had been brief, the sentencing judge had considered all of the circumstances potentially justifying a departure from the Guidelines and found them insufficient, and the decision not to depart was reasonable and justified. ${ }^{117}$ The Court stated that district courts should start the sentencing process by calculating the proper range under the Guidelines. ${ }^{118}$

The Court also found that Apprendi-type rules applied to the finding of aggravating facts and circumstances necessary to establish eligibility for the death penalty in Ring v. Arizona. ${ }^{119}$ The Court found that such factors are the functional equivalent of elements of a greater offense, and must be found beyond a reasonable doubt by a jury. ${ }^{120}$

Justice Scalia authored a concurrence to Justice Ginsburg's lead opinion in this case. ${ }^{121}$ Justice Scalia disagreed with the reasoning that aggravating factors must be found in order to impose a capital sentence, but stated that the Sixth Amendment requires all elements necessary to impose a certain level of punishment, no matter what they are called, to be found by a jury beyond a reasonable doubt (or admitted). ${ }^{122}$ Justice Scalia also noted with concern

the accelerating propensity of both state and federal legislatures to adopt "sentencing factors" determined by judges that increase punishment beyond what is authorized by the jury's verdict, and my witnessing the belief of a near majority of my colleagues that this novel practice is perfectly OK, cause me to believe that our people's traditional belief in the right of trial by jury is in perilous decline. That decline is bound to be confirmed, and indeed accelerated, by the repeated spectacle of a man's going to his death because a judge found that an aggravating factor existed. We cannot preserve our veneration for the protection of the jury in criminal cases if we render ourselves callous to the need for that protection by regularly imposing the death penalty without it. ${ }^{123}$

Justice O'Connor filed a dissenting opinion in Ring, deciding that rather than

115. Id. at 346 .

116. Id. at 359-60.

117. Id. at 359 .

118. Id. at $350-51$.

119. 536 U.S. 584 (2002).

120. Id. at 609 .

121. Id. at 610 (Scalia, J., concurring).

122. Id. at 611-12.

123. Id. (emphasis in original, internal citations omitted). 
reaffirming Apprendi, it should have been overturned in this case. ${ }^{124} \mathrm{O}^{\prime}$ Connor noted that, as she had predicted in her dissenting opinion in Apprendi, a "flood of petitions" had been released by convicted defendants seeking to overturn sentences and convictions. ${ }^{125}$ She noted that, as of May 31, 2002, 1,802 criminal appeals had been decided by the U.S. Courts of Appeals based on Apprendi. ${ }^{126}$ She also wrote that the decision in Ring probably invalidated the death penalty systems of Colorado, Idaho, Montana, Nebraska, and Arizona, and endangered the hybrid systems of Indiana, Delaware, Florida, and Alabama. ${ }^{127}$

Precedent set prior to the adoption of the rules also affects the interpretation of the SRA. In Winship, ${ }^{128}$ Winship had been accused of crimes which would have been larceny had he been an adult. ${ }^{129}$ The judge made a determination based upon a preponderance of the evidence and ordered Winship to a training school for one and a half years, with possible extensions of up to six years. ${ }^{130}$

The Court reiterated that the Due Process Clause protects the accused against conviction except where there is proof beyond a reasonable doubt of each fact necessary to constitute the crime with which he is charged. ${ }^{131}$ In resolving this case in Winship's favor, the Court stated that the criminal constitutional safeguards of notice of charges, right to counsel, the rights of confrontation and examination, and privilege against self incrimination are "as much required during the adjudicatory stage of a delinquency proceeding" as they are in adult criminal cases. ${ }^{132}$

Mullaney v. Wilbur ${ }^{133}$ further reinforced this view. At trial, Mullaney had been required to prove that he acted in the heat of passion upon sudden provocation in order to be found guilty of manslaughter, rather than murder, when he killed another man after a homosexual advance. ${ }^{134}$ Ruling on Wilbur's writ of habeas corpus, the federal district court overturned this decision, holding that Winship required that the prosecution prove beyond a reasonable doubt that Wilbur had not acted in the heat of passion on sudden provocation because murder requires malice aforethought; murder and manslaughter are separate crimes, not simple gradations of a single offense. ${ }^{135}$

Following further action in the state courts, and a reapplication of Winship by the Court of Appeals, the U.S. Supreme Court granted certiorari. ${ }^{136}$ The Court

124. Id. at 619-20 (O'Connor, J., dissenting).

125. Id.

126. $I d$. at 620 .

127. Id. at 620-21.

128. 397 U.S. 358 (1970).

129. Id. at 360 .

130. Id. at 359-60.

131. Id. at 375.

132. Id. at 368 .

133. 421 U.S. 684 (1975).

134. Id. at 685-87.

135. Id. at 688.

136. Id. at 689-90. 
stated that requiring the defendant to prove by a preponderance of the evidence that he acted in the heat of passion means he can be given a life sentence where it is just as likely as not that he deserves a lesser sentence. ${ }^{137}$ The Court held that the Due Process Clause, therefore, "require[d] the prosecution to prove beyond a reasonable doubt the absence of the heat of passion on sudden provocation where the issue is properly presented in a homicide case[,]" and affirmed the holding of the Court of Appeals. ${ }^{138}$

However, in Patterson v. New York, ${ }^{139}$ the Court indicated that there are limits to what the prosecution must prove under Mullaney. ${ }^{140}$ Patterson had appealed his conviction for murdering his wife's friend, claiming that it was an unconstitutional violation of the Fourteenth Amendment for the State to require him to prove his affirmative defense of extreme emotional disturbance. ${ }^{141}$

Under existing New York law, second-degree murder did not require malice aforethought, it merely requires the intent to cause the death of another and causing the death of that person or another person. ${ }^{142}$ New York also recognizes the crime of manslaughter, which can be constituted by killing another while under the influence of extreme emotional distress. ${ }^{143}$ Patterson raised this defense at trial. ${ }^{144}$ The U.S. Supreme Court upheld his conviction, declining to adopt a rule that would require prosecutors to disprove beyond a reasonable doubt every possible affirmative defense that a defendant might possibly have. ${ }^{145}$

The Court went on to find that this may lead some to believe that legislatures could reallocate burdens of proof by labeling many elements of existing crimes as affirmative defenses. ${ }^{146}$ However, the Court stated that there are Constitutional limits that cannot be crossed in this regard, and that established long before Winship were the traditions that the prosecution must prove guilt beyond a reasonable doubt and that various affirmative defense were up to the defendant to prove. ${ }^{147}$

In McMillan v. Pennsylvania, McMillan was convicted of aggravated assault (shooting another person) by a jury. ${ }^{148}$ Sentencing for this crime called for eleven and a half to twenty three months, but the judge found by a preponderance of the evidence that McMillan also "visibly possessed a firearm," which called for an

137. Id. at 703 .

138. Id. at 703-04.

139. 432 U.S. 197 (1977).

140. Id. at 215-16.

141. Id. at 201.

142. N.Y. PENAL LAW $\S 125.25$ (McKinney 1975).

143. Id. $\S 125.20(2)$.

144. Patterson, 432 U.S. at 198-99.

145. Id. at 210.

146. Id.

147. Id. at 211.

148. 477 U.S. 79 (1986). 
enhanced mandatory minimum sentence of five years. ${ }^{149}$

While this makes little sense as an enhancement from the perspective that the underlying crime (shooting someone) required the use of a firearm, this sentence was upheld by the Court. ${ }^{150}$ The underlying offense carried a potential penalty of five years, ${ }^{151}$ and therefore this sentence did not exceed the allowable under Apprendi. There was no Sixth Amendment violation because this enhancement did not authorize or impose a penalty beyond the statutory norm, it was only applicable after the offender had been convicted of an underlying crime, it did not create a new crime or increase the maximum penalty for an existing crime, and it did not change the definition of any existing crime. ${ }^{152}$

The Court stated that the limits of Patterson were not transgressed in this case. ${ }^{153}$ In other words, the limits set by Patterson on the State's ability to determine which facts serve as an element of the crime had not been exceeded. The Court held that:

[W]e have never attempted to define precisely the constitutional limits noted in Patterson, i.e., the extent to which due process forbids the reallocation or reduction of burdens of proof in criminal cases, and do not do so today, we are persuaded by several factors that Pennsylvania's Mandatory Minimum Sentencing Act does not exceed those limits. ${ }^{154}$

The Apprendi line of cases forbids imposition of a sentence greater than the maximum allowable under the facts admitted or proven beyond a reasonable doubt to a jury, but does this affect a judge's ability to impose consecutive sentences? In State v. Abdul Abdullah, ${ }^{155}$ Abdullah had been found guilty of murder, burglary, and multiple weapons-possession crimes. ${ }^{156}$ At the sentencing hearing, the court stated that there were no mitigating factors and that four aggravating factors were present: the nature of the offense, the risk of additional offenses, a prior criminal record, and the need to deter the defendant. ${ }^{157}$ The judge sentenced Abdullah to life imprisonment with a thirty-year parole disqualifier for the murder conviction and a consecutive ten-year term with five-year parole disqualifier for one of the burglary convictions. ${ }^{158}$

On appeal, Abdullah argued that the jury had not determined essential facts

149. Id. at $81-82$, n.2., 95 .

150. Id. at 93 .

151. Id. at $81-82$.

152. Id. at 83; see also United States v. Vallejo, 226 Fed. App'x 607 (7th Cir. 2007) (holding that the Fifth Amendment does not require factual findings made to support an enhancement under the Guidelines to be supported by proof beyond a reasonable doubt, as long as the finding relates only to the Guideline range and not the statutory maximum).

153. McMillian, 477 U.S. at 86.

154. Id.

155. 878 A.2d 746 (N.J. 2005).

156. Id. at $748-49$.

157. Id. at 749 .

158. Id. 
for the imposition of the maximum term for burglary and murder, for the parole disqualification on the burglary charge, or for the imposition of consecutive sentences, and therefore his Sixth Amendment rights had been violated. ${ }^{159}$ The New Jersey Court of Appeals decided that, although the presumptive term for burglary was seven years, the enhancement to ten years was based on Abdullah's prior convictions (although the trial court had also considered the serious nature of the crime, a fact not specifically found by the jury, the court of appeals felt the trial court had not relied on this factor). ${ }^{160}$ The court also found that murder has no presumptive sentence and therefore this penalty did not violate Blakely because it fell within the normal range for murder of thirty years to life. ${ }^{161}$ The court also held that the Sixth Amendment under Apprendi and Blakely does not require a jury to find facts necessary to impose parole disqualifications or consecutive sentences. ${ }^{162}$

The New Jersey Supreme Court overturned and remanded the sentence for burglary, based on its view that the maximum sentence that may be imposed is the presumptive term based solely on facts found by a jury (or admitted), and thus the enhancement beyond seven years for burglary could not stand because the trial court may have relied on the serious nature of the crime, a fact which had not been specifically found by the jury. ${ }^{163}$ The New Jersey Supreme Court upheld the constitutionality of the other sentences imposed, although it did remand the parole disqualifier on the burglary charge, as the underlying sentence was to be reconsidered. ${ }^{164}$ Neither the parole disqualifiers nor the imposition of consecutive sentences upon judge-found factors were found to violate the Constitution. ${ }^{165}$ This court found no violation of Apprendi or Blakely by imposition of parole disqualifiers or consecutive sentencing, and no presumptive preference for consecutive sentencing, but did remand this issue for the court below to state its reasons for imposing consecutive sentences. ${ }^{166}$

In Southern Union Co. v. United States ${ }^{167}$ the court again considered the scope of its Sixth Amendment jurisprudence as construed by Apprendi ${ }^{168}$ In this case, a jury convicted Southern Union Company of storing liquid mercury in

159. Id. at 750 .

160. Id.

161. Id.

162. Id.

163. Id. at 751-52.

164. Id. at 755 .

165. Id.

166. Id. at 756-57; see also Douglas v. United States, No. 04-2066, 2005 U.S. Dist. LEXIS 34382, at $* 21$ (D. N.J. July 18, 2005 (holding that a court was not required to make specific findings of factors from the Guidelines to impose consecutive sentences). However, see United States v. Thompson, 170 Fed. App'x 846, 847 (4th Cir. 2006) (holding that a court imposing a sentence outside the Guidelines range must state its reasons for doing so).

167. 567 U.S. 343 (2012).

168. Id. at 348 . 
violation of the Resource Conservation and Recovery Act. ${ }^{169}$ The violation is punishable by a fine of up to $\$ 50,000$ for each day of the violation. ${ }^{170}$ Although the jury did not consider the exact duration of Southern Union Company's violation, a maximum fine of $\$ 38.1$ million was established at sentencing. ${ }^{171} \mathrm{In}$ its briefing before the Court, the Government "concede[d] the District Court made factual findings that increased both the "potential and actual" fine imposed. ${ }^{172}$ The Court noted that " $[\mathrm{t}]$ his is exactly what Apprendi guards against: judicial factfinding that enlarges the maximum punishment a defendant faces beyond what the jury's verdict or the defendant's admissions allow." 173 Therefore, the Court held that the rule of Apprendi applies to the imposition of criminal fines. ${ }^{174}$

After the Court used Apprendi, and the cases that followed, to discuss statutory maximum sentences, the Court decided Florida v. Harris ${ }^{175}$ and Alleyne v. United States ${ }^{176}$ to rule on the constitutional issues related to mandatory minimum sentences.

In Alleyne, Alleyne and an accomplice devised a plan to rob a store manager as he delivered the store's daily deposit to the bank. ${ }^{177}$ Alleyne was charged with, among other crimes, using or carrying a firearm in relation to a crime of violence. ${ }^{178}$ The crime carries a five-year minimum sentence, and that sentence increases to a seven-year minimum if the firearm is brandished and a ten-year minimum if the firearm is discharged during the commission of the crime. ${ }^{179}$

At trial, the jury found that Alleyne used or carried the firearm in relation to the crime, but the jury did not find beyond a reasonable doubt that the firearm was brandished. ${ }^{180}$ However, the presentence report recommended a mandatory minimum sentence of seven years based on the judge's finding that Alleyne brandished a firearm during the commission of the crime. ${ }^{181}$

During sentencing, Alleyne objected and argued "that it was clear from the verdict form that the jury did not find brandishing beyond a reasonable doubt and that he was subject only to the 5-year minimum sentence for 'us[ing] or carr[ying] a firearm." ${ }^{182} \mathrm{He}$ "contended that raising his mandatory minimum sentence based on a sentencing judge's finding that be brandished a firearm would violate his

169. Id. at $346-47$.

170. Id. at 347 .

171. Id.

172. Id. at 353 .

173. Id.

174. Id. at 360.

175. 568 U.S. 237 (2013).

176. 570 U.S. 99 (2013).

177. Id. at 103-04.

178. Id. at 104.

179. Id. at 103-04.

180. Id. at 104.

181. Id.

182. Id. 
Sixth Amendment right to a jury trial." 183

The District Court relied on the Court's holding in Harris and denied the objection based on the determination that brandishing was a sentencing factor that a judge was permitted to find by a preponderance of evidence without violating constitutional protections, because judicial factfinding which increases a mandatory minimum sentence, is permitted pursuant to the Court's Sixth Amendment jurisprudence. ${ }^{184}$

The Court, in Harris and Alleyne, was presented with a nearly identical question. The Court decided Harris first, and chose to draw "a distinction between facts that increase the statutory maximum and facts that increase only the mandatory minimum"185 sentence by holding that "judicial factfinding that increases the mandatory minimum sentence for a crime is permissible under the Sixth Amendment." 186

After Harris, the Court seized the opportunity in Alleyne to harmonize its Sixth Amendment jurisprudence in Harris with Apprendi. In general, the Court sought to reconcile its holding that facts which increase a sentence past the statutory maximum are elements of the crime that must be submitted to a jury while facts that increase the mandatory minimum sentence are sentencing factors that may be determined by the sentencing judge. ${ }^{187}$

Ultimately, in Alleyne, the Court overruled Harris, and held that "[b]ecause the finding of brandishing increased the penalty to which the defendant was subjected, it was an element, which had to be found by the jury beyond a reasonable doubt." 188

As the Sentencing Guidelines are amended throughout the years, sentencing judges are tasked with applying new versions of the Guidelines that suggest different sentence ranges for identical crimes compared to previous versions of the Guidelines. ${ }^{189}$ According to the Guidelines, the courts "shall use the Guidelines Manual in effect on the date that the defendant is sentenced."190 However, the Court and the Guidelines consider an exception to this rule that is founded in the ex post fact clause of the Constitution. ${ }^{191}$

In Peugh v. United States, ${ }^{192}$ Marvin Peugh challenged his 2009-conviction for bank fraud that occurred in 1999 and 2000. ${ }^{193}$ During sentencing, the district court relied on the 2009 version of the Sentencing Guidelines and sentenced

183. Id

184. Id.

185. Id. at 102 .

186. Id.

187. See generally id.

188. Id. at 117.

189. The 2016 Guideline Manual is the most current at the time of this publication.

190. U.S. Sentencing Guidelines Manual § 1B1.11(a)(U.S. Sentencing Comm'n 2016).

191. Id. § 1B1.11(b)(1).

192. 569 U.S. 530 (2013).

193. Id. at 533-34. 
Peugh to seventy months in prison. ${ }^{194}$ Peugh argued that the Constitution's ban on ex post facto laws required the court to use the version of the Guidelines in effect when Peugh committed the crimes - which suggested a sentencing range of 30-37 months. ${ }^{195}$ The Government argued in principal that the post-Booker "Sentencing Guidelines lack sufficient legal effect to attain the status of a 'law' within the meaning of the Ex Post Facto Clause[,]" and therefore there exists no constitutional violation. ${ }^{196}$

The Court was not persuaded and held that the sentencing judge must refer to the Guidelines in effect when the crime was committed, especially when the Sentencing Guidelines promulgated subsequent to the commission of the crime create a "significant risk" of a higher sentence. ${ }^{197}$

\section{CONCLUSION}

It is clear that Apprendi and Blakely are invoked only when going beyond the statutory maximum penalty for a crime, not before, and that Alleyne offers guidance regarding mandatory minimum sentences. The SRA took sentencing discretion from the judges in an attempt to create a determinate sentencing system and Booker returned much of that discretion to the judges. However, the Guidelines remain and must be consulted, and the scope of the discretion now afforded judges remains an open question, but the Court is willing to offer its guidance. As Justice Stevens pointed out in his dissent in Booker, the decision to retain the Guidelines but excise the mandatory provisions rested on the assumption that Congress would not have made the Guidelines mandatory had they known that doing so would have required enhancements to jury fact finding under the Sixth Amendment and that a re-adoption of the SRA by Congress would repudiate this premise. ${ }^{198}$

While trial court judges must begin their sentencing calculations by consulting the Guidelines, we also know that some level of deference is due trial courts in assigning penalties. A sentence may be afforded a presumption of reasonableness if the Guidelines are properly consulted. Sentencing decisions by trial courts will be reviewed for their reasonableness, using an abuse of discretion standard.

Just how far legislatures and courts can go in designating enhancements to penalties as sentencing factors rather than elements of crimes remains unknown. However, these limits are beginning to take shape. For example, Apprendi and its progeny do not appear to bar judges from imposing consecutive sentences or parole disqualifiers.

194. Id. at 534-35.

195. Id. at 545.

196. Id. at 546 (emphasis in original).

197. Id. at 549-50.

198. 543 U.S. 220, 281-86 (2005) (Stevens, J., dissenting in part). 

SENTENCING GUIDELINES

The tension between continued consultation of the Guidelines and allowing judges to utilize discretion in sentencing is ongoing. Given the unsettled nature of the law in this area, the continuing discussion in the U.S. Supreme Court and lower courts and the specter of possible Congressional action, further developments are likely. 


\section{APPENDIX A}

\begin{tabular}{|c|c|c|c|c|c|c|c|}
\hline & \multicolumn{7}{|c|}{$\begin{array}{l}\text { SENTENCING TABLE } \\
\text { (in months of imprisonment) }\end{array}$} \\
\hline & \multirow[b]{2}{*}{$\begin{array}{c}\text { Offense } \\
\text { Level }\end{array}$} & \multicolumn{6}{|c|}{ Criminal History Category (Criminal History Points) } \\
\hline & & $\underset{(0 \text { or } 1)}{I}$ & $\underset{\text { (E or } 3)}{\text { II }}$ & $\underset{(4,5,6)}{\text { III }}$ & $\underset{(7,8,9)}{\text { IV }}$ & $\begin{array}{c}V \\
(10,11,12)\end{array}$ & $\begin{array}{c}\text { VI } \\
\text { (13 or more) }\end{array}$ \\
\hline \multirow{8}{*}{ Zone A } & 1 & $0-6$ & $0-6$ & $0-6$ & $0-6$ & $0-6$ & $0-6$ \\
\hline & 2 & $0-6$ & $0-6$ & $0-6$ & $0-6$ & $0-6$ & $1-7$ \\
\hline & a & $0-6$ & $0-6$ & $0-6$ & 0-6 & $2-8$ & $3-9$ \\
\hline & 4 & $0-6$ & $0-6$ & $0-6$ & $2-8$ & $4-10$ & $6-12$ \\
\hline & 5 & $0-6$ & $0-6$ & $1-7$ & $4-10$ & $6-12$ & $9-15$ \\
\hline & 6 & $0-6$ & $1-7$ & $2-8$ & $6-12$ & $9-15$ & $12-18$ \\
\hline & 7 & $0-6$ & $2-8$ & $4-10$ & $8-14$ & $12-18$ & $15-21$ \\
\hline & 8 & $0-6$ & $4-10$ & $6-12$ & $10-16$ & $15-21$ & $18-24$ \\
\hline \multirow{3}{*}{ Zone B } & 9 & $4-10$ & $6-12$ & 8-14 & $12-18$ & $18-24$ & $21-27$ \\
\hline & 10 & $6-12$ & $8-14$ & $10-16$ & $15-21$ & $21-27$ & $24-30$ \\
\hline & 11 & 8-14 & $10-16$ & $12-18$ & $18-24$ & $24-30$ & $27-33$ \\
\hline \multirow{2}{*}{ Zone C } & 12 & $10-16$ & $12-18$ & $15-21$ & $21-27$ & $27-33$ & $30-37$ \\
\hline & 18 & $12-18$ & $15-21$ & $18-24$ & $24-30$ & $30-37$ & $33-41$ \\
\hline \multirow{30}{*}{ Zone D } & 14 & $15-21$ & $18-24$ & $21-27$ & $27-33$ & $33-41$ & $37-46$ \\
\hline & 15 & $18-24$ & $21-27$ & $24-30$ & $30-37$ & $37-46$ & $41-51$ \\
\hline & 16 & $21-27$ & $24-30$ & $27-33$ & $33-41$ & $41-51$ & $46-57$ \\
\hline & 17 & $24-30$ & $27-33$ & $30-37$ & $37-46$ & $46-57$ & $51-63$ \\
\hline & 18 & $27-33$ & $30-37$ & $33-41$ & $41-51$ & $51-63$ & $57-71$ \\
\hline & 19 & $30-37$ & $33-41$ & $37-46$ & $46-57$ & $57-71$ & $63-78$ \\
\hline & 20 & $33-41$ & $37-46$ & $41-51$ & $51-63$ & $63-78$ & $70-87$ \\
\hline & 21 & $37-46$ & $41-51$ & $46-57$ & $57-71$ & $70-87$ & $77-96$ \\
\hline & 22 & $41-51$ & $46-57$ & $51-63$ & $63-78$ & $77-96$ & $84-105$ \\
\hline & 28 & $46-57$ & $51-63$ & $57-71$ & $70-87$ & $84-105$ & $92-115$ \\
\hline & 24 & $51-63$ & $57-71$ & $63-78$ & $77-96$ & $92-115$ & $100-125$ \\
\hline & 25 & $57-71$ & $63-78$ & $70-87$ & $84-105$ & $100-125$ & $110-137$ \\
\hline & 26 & $63-78$ & $70-87$ & $78-97$ & $92-115$ & $110-137$ & $120-150$ \\
\hline & 27 & $70-87$ & $78-97$ & $87-108$ & $100-125$ & $120-150$ & $130-162$ \\
\hline & 28 & $78-97$ & $87-108$ & $97-121$ & $110-137$ & $130-162$ & $140-175$ \\
\hline & 29 & $87-108$ & $97-121$ & $108-135$ & $121-151$ & $140-175$ & $151-188$ \\
\hline & 30 & $97-121$ & $108-135$ & $121-151$ & $135-168$ & $151-188$ & $168-210$ \\
\hline & 31 & $108-135$ & $121-151$ & $135-168$ & $151-188$ & $168-210$ & $188-235$ \\
\hline & 32 & $121-151$ & $135-168$ & $151-188$ & $168-210$ & $188-235$ & $210-262$ \\
\hline & 33 & $135-168$ & $151-188$ & $168-210$ & $188-235$ & $210-262$ & $235-293$ \\
\hline & 34 & $151-188$ & $168-210$ & $188-235$ & $210-262$ & $235-293$ & $262-327$ \\
\hline & 35 & $168-210$ & $188-235$ & $210-262$ & $235-293$ & $262-327$ & $292-365$ \\
\hline & 36 & $188-235$ & $210-262$ & $235-293$ & $262-327$ & $292-365$ & $324-405$ \\
\hline & 37 & $210-262$ & $235-293$ & $262-327$ & $292-365$ & $324-405$ & 360-life \\
\hline & 38 & $235-293$ & $262-327$ & $292-365$ & $324-405$ & 360 -life & 360 -life \\
\hline & 39 & $262-327$ & $292-365$ & $324-405$ & 360-life & 360-life & 360-life \\
\hline & 40 & $292-365$ & $324-405$ & 360-life & 360-life & 360-life & 360-life \\
\hline & 41 & $324-405$ & 360-life & 360-life & 360-life & 360-life & 360-life \\
\hline & 42 & 360-life & 360 -life & 360-life & 360-life & 360-life & 360-life \\
\hline & 43 & life & life & life & life & life & life \\
\hline
\end{tabular}

